Open Access

\title{
Consumer acceptance of an iron bean variety in Northwest Guatemala: the role of information and repeated messaging
}

\author{
Salomón Pérez ${ }^{1 *}$, Adewale Oparinde ${ }^{2}$, Ekin Birol ${ }^{2}$, Carolina Gonzalez ${ }^{1}$ and Manfred Zeller ${ }^{3}$
}

\author{
* Correspondence: \\ s.p.suarez@cgiar.org \\ ${ }^{1}$ Centro Internacional de Agricultura \\ Tropical (CIAT), Cali, Colombia \\ Full list of author information is \\ available at the end of the article
}

\begin{abstract}
Micronutrient malnutrition affects 2 billion people worldwide and biofortification could prove to be a cost-effective solution to its alleviation. The aims of this study are as follows: (i) to understand consumer acceptance of the main sensory characteristics such as taste, color, texture, etc., of an iron-enriched bean variety compared to a popular traditional one ("parramos"); (ii) to measure consumer willingness to pay (WTP) for an iron-enriched bean variety compared to a traditional one; (iii) to investigate the role of nutrition information; and (iv) to understand the impact of information repetition on consumer acceptance. To achieve this, a home use testing (HUT) method and a Becker-DeGroot-Marshak mechanism were used. The results indicate that consumers equally preferred the iron-enriched and the local bean varieties, although some minor differences were found in some of the sensory characteristics. Although the mean WTP for the iron-enriched bean variety was higher, the difference was not statistically significant among the groups evaluated. The information provided and the order of variety delivery play a significant role in consumer acceptance for the iron-enriched variety, and repetition in providing information had a positive impact depending on the type of message provided and on who received it (e.g., men or women, more educated respondents). Potential censored bids were found due to the nature of the currency interval and some transaction costs.
\end{abstract}

Keywords: Consumer acceptance, Willingness to pay, Iron-enriched bean, Nutritional information, Guatemala

\section{Background}

Micronutrient malnutrition, or hidden hunger, affects 2 billion people worldwide. One potential solution to its alleviation is biofortification, i.e., the process of breeding and delivering staple food crops with higher micronutrient content. Biofortified varieties and traditional varieties differ in their micronutrient content while their color, size, texture, and other organoleptic and agronomic attributes are usually similar. Varieties with higher carotenoid content may differ in color, i.e. they are often more yellow. Biofortification could prove to be a cost effective and sustainable strategy, especially in the rural areas of many developing countries where there is high production and consumption of staple crops and where micronutrient deficiency rates are high (Meenakshi et al. 2012; Saltzman et al. 2013). In recent years, several bean, rice and

(c) The Author(s). 2018 Open Access This article is distributed under the terms of the Creative Commons Attribution 4.0 International License (http://creativecommons.org/licenses/by/4.0/), which permits unrestricted use, distribution, and reproduction in any medium, provided you give appropriate credit to the original author(s) and the source, provide a link to the Creative Commons license, and indicate if changes were made. 
maize varieties with higher micronutrient levels were released in various Latin American and Caribbean (LAC) countries. Moreover, many promising new varieties with even higher levels of micronutrients are in the pipeline for release. Biofortification is increasingly gaining momentum in LAC with some countries such as Brazil and Panama, including them in their public regulations and many others such as Colombia and Honduras considering it as an alternative intervention to strengthen their efforts against micronutrient malnutrition, particularly in rural areas. Despite all these efforts and the improved momentum, there has been relatively little research on evaluating consumer preferences for, and acceptability of, these biofortified varieties by target populations in the region.

Guatemala is one of the LAC countries with the highest proportion of population living in rural areas. Most rural Guatemalans are indigenous and have a deep-rooted bean consumption tradition. An average Guatemalan consumes $34 \mathrm{~g}$ of beans per day (INE (Instituto Nacional de Estadística) 2006). According to the Micronutrients National Survey carried out by the Ministry of Public Health and Social Assistance (MSPS) between 2009 and 2010, iron deficiency was an important public health problem, as 24\% of the children and $20 \%$ of the women in rural areas do not receive sufficient iron in their diets. In general, iron deficiency in rural areas is slightly higher in indigenous communities than in non-indigenous ones ("mestizos"). Given the high bean consumption and high iron deficiency rates especially in rural areas, biofortifying beans with iron could be a promising solution to reduce iron deficiency prevalence in Guatemala.

The success of biofortification depends on whether biofortified foods are accepted and consumed by target populations (Meenakshi et al. 2012). Acceptance depends on consumer preferences for various organoleptic characteristics (e.g., taste, color or texture), as well as their relative price perceptions for biofortified foods. This study contributes to the evaluation of consumer preferences for and acceptance of biofortified foods in the Latin American context. In this study, we use similar methods to those used in the African and Asian contexts (see Naico and Lusk 2010; Chowdhury et al. 2011; Meenakshi et al. 2012; Banerji et al. 2013; Oparinde et al. 2016a, b), allowing the comparison of biofortified food acceptance results across regions.

Several studies have been conducted in developing countries to investigate consumer acceptance of biofortified foods and the role of information on the nutritional benefits of such foods in driving demand (see for example, Meenakshi et al. 2012 and Banerji et al. 2013 for vitamin A-enriched maize in Zambia and Ghana, respectively; Naico and Lusk 2010 and Chowdhury et al. 2011, for vitamin A-enriched orange sweet potato in Mozambique and Uganda, respectively; Oparinde et al. 2016a for vitamin A-enriched cassava in Nigeria; and Banerji et al. 2015 for iron-enriched pearl millet in India). According to Meenakshi et al. (2012), the impact of information on acceptability that has been studied in the literature is complex to interpret as successful nutrition messaging often requires the repetition of messages.

This study aims to examine Guatemalan consumers' preferences for an iron-enriched bean variety (IB variety) known as "super chiva" (74 ppm of iron) compared to the most popular local bean variety known as "parramos" (50 ppm of iron). The aims of this study are (i) to understand consumer acceptance of the main organoleptic characteristics of an iron-enriched bean variety compared to the traditional one using a sensory evaluation (hedonic scores); (ii) to measure consumer willingness to pay (WTP), i.e., 
the price premium/discount for the IB variety compared to the local one, and the variation of this premium/discount with consumer-specific socioeconomic characteristics; (iii) to investigate whether nutritional information has an impact on driving demand for biofortified foods in the Latin American (i.e., Guatemalan) context, as has been shown in Africa and Asia; and (iv) to understand the impact of the frequency with which information is given on consumer acceptance.

The following section presents the details of the selection criteria for the study site, the sampling design, the elicitation and data collection methods, the information, models, survey, tools and analyses used. The "Results" section describes and summarizes the main results obtained, and the "Conclusions and discussion" section contains a short discussion and the conclusions, including some policy recommendations.

\section{Methods}

\section{Study site}

The data collection was conducted in August 2013 in San Sebastian Huehuetenango municipality, in Huehuetenango province, in northwest Guatemala near the Mexican border. The prevalence of chronic malnutrition in this municipality is $72.2 \%$ and it ranks 27 out of 330 municipalities in Guatemala (Gobierno de Guatemala 2012). Huehuetenango was selected as the study site because of its high levels of bean consumption and production, and high levels of iron deficiency which affects over one-third of children and pregnant women (MSPS (Ministerio de Salud Pública y Asistencia Social) 2012). Moreover, it had suitable agro-ecological conditions for production of the "super chiva" variety, as demonstrated by agronomical tests carried out by the Science and Agricultural Technology Institute of Guatemala (ICTA).

\section{Sampling design}

Power calculations were conducted to determine a statistical significant number of respondents that should be surveyed in this study.

Bean prices in northwest Guatemala vary according to bean color. Red and white bean varieties are the most expensive and are usually consumed on special occasions, while black varieties, which are consumed daily, are the cheapest. In July 2013, the average market price for the traditional black bean varieties was 5 Quetzals $^{1}$ per pound. ${ }^{2}$ Based on previous studies (Chowdhury et al. 2011; Meenakshi et al. 2012; Banerji et al. 2013), a 15\% effect on WTP was anticipated, corresponding to 0.5 Quetzals with a standard deviation of 2.5 Quetzals. Using a significance level of $5 \%$ and a power of 0.8 , a sample size of 120 households $(\mathrm{HH})$ per treatment (3 treatments) was estimated.

The sampling strategy established a minimum sample size of 360 households from different communities in the San Sebastian Huehuetenango municipality. But as there was no reliable secondary data (from any recent census) or any official information on population numbers in the municipality available, the study asked local experts and community leaders in the study site to provide an estimate of the population numbers in each community.

The data collection took place before the harvesting season and coincided with the rainy season, which meant that transportation of the enumerators' teams to some communities was difficult, if not impossible. More remote communities had higher security risks and their members were more reluctant to participate in any 
kind of study. As a result, a list of 20 accessible and less remote communities was drawn up, and 12 communities were randomly chosen from this list. The number of participating households per community was determined according to the relative proportion of the population among the listed communities. The enumerators selected every fifth household on the list in those communities with 250 or less households, or every seventh household on the list in those communities with more than 250 households; selection was proportional to the community's size. As a result, we obtained a self-weighing sample of households, which represented the safer and less remote parts of the municipality of San Sebastian Huehuetenango.

\section{Data collection}

In this study, two black bean varieties were used-one was an iron-enriched bean (IB) variety ("super chiva") that has $74 \mathrm{ppm}$ of iron and the other one was the traditional local variety ("parramos") that has $50 \mathrm{ppm}$ of iron and is commonly consumed in the study area. The IB variety used in this study was procured from Instituto de Ciencia y Tecnología Agrícola (ICTA) (Spanish acronym) which had been cultivated in the first season of 2013, whereas the traditional variety was obtained from a local farmer who had produced it in the same season.

Data was collected using the home use testing (HUT) method in which a selected household received $1 \mathrm{lb}$. of grain of both bean varieties for 2 days (one variety on each day, selected in random order) to cook and eat at home. A total of $1 \mathrm{lb}$. of beans was deemed to be sufficient for an average household's breakfast and lunch consumption based on the average household size and demographics and information on the bean quantity consumed per person in the region. Each consumer were encouraged to experience and evaluate the following sensory and cooking attributes: raw bean color, raw bean size, bean taste, cooking time, cooked bean thickness, cooked bean toughness, and the overall evaluation. Each attribute was evaluated on a 7-point Likert scale ranging from 1 (dislike very much) to 7 (like very much); other levels were 2 , dislike; 3 , dislike a little; 4 , neither like nor dislike; 5 , like a little; and 6, like. To investigate the role of information repetition on the nutritional value of the iron-enriched bean cultivar, the sample was divided into three treatments. In the first treatment (control group), none of the respondents received any information about the nutritional benefits of the IB variety tested; in the second one, respondents received information on the IB variety on the first day; and in the third group, they received the information on the IB variety three times, once on each day. The participants at each location were randomly assigned to one of the three treatments.

Before describing the study and asking the participants' consent to participate, subjects were asked about their knowledge of IB varieties. To avoid biasing the results, those who stated any kind of knowledge were not invited to join this study (and the next fifth or seventh household on the list was selected instead). Household members who were responsible for food purchasing and cooking (one per household) were asked to participate in this study.

To prevent further nutrition information contamination, the control group (who did not receive any information) was dealt with first (during the first week), and the other two information treatments were completed in the following 2 weeks. Although we tried to minimize information contamination, there may have been some across-treatment contamination in the Becker-DeGroot-Marschak (BDM) auction-like mechanism and payment requests for the bean varieties evaluated (Oparinde et al. 2016c). 
The data collection flow from each household was as follows:

Day 1 (early afternoon): The household randomly received $1 \mathrm{lb}$. of one of the bean samples. The respondents were asked to cook the sample using their usual cooking practices and were told to avoid mixing the bean sample with any other bean variety they may already have had at home. Households were visited early in the afternoon, because they usually cooked their beans in the evening to consume at breakfast and lunch the following day. Each household was given 1 day to cook and consume the bean variety. One day was thought to be a sufficient amount of time for the households to form an opinion about the variety, while reducing the risk of information contamination through social networks. Households were then visited in the afternoon, and they were asked for a follow-up appointment on the next day in the afternoon. The follow-up appointment was set for after lunch to minimize the recall bias of the organoleptic characteristics of the bean varieties. On day 1 , those in treatments 2 and 3 received the nutritional message for the first time just before they received the bean sample.

Day 2 (after lunch): On the next day, the enumerator visited the same household to conduct the sensory evaluation of the variety delivered the day before and to give the sample of the second variety. Respondents on treatment 3 received the nutritional information for a second time after they had done the sensory evaluation for the first bean sample.

Day 3 (after lunch): The sensory evaluation for the second sample was carried out on the third day along with the BDM auction-like mechanism for the elicitation of respondent WTP for both types of beans evaluated. Those in treatment 3 received the nutritional information for the third and last time just before the sensory evaluation and the BDM auction-like mechanism were carried out.

The incentive-compatible BDM was chosen due its suitability in rural settings (Banerji et al. 2013) and its applicability for individuals, as it does not require a group of subjects (Lusk and Shogren 2007). According to De Groote et al. (2011), the BDM mechanism is a much faster and efficient method than other experimental auctions, especially in a rural context. In preference elicitation studies, a participation fee is commonly given to the participants at the beginning of the experiment to avoid participants from being out-of-pocket when making purchases. However, standard economic theory suggests that initial endowments can distort optimal bidding behavior (Corrigan and Rousu 2006), and empirical evidence shows mixed results (Loureiro et al. 2003; Morawetz et al. 2011; Banerji et al. 2013). In this study, we did not include participation fees to avoid such biases and to make the experiment as real as possible. Participants were told that they would be paying out their own pockets for beans if they "won" either one of the bean varieties in the auction-like mechanism.

Enumerators explained to the participants how the BDM mechanism worked. They explained that bidding a higher price than their real WTP could result in them paying a higher price than the one they were originally willing to pay, whereas biding a lower price than their real WTP could result in them losing out on a profitable opportunity to purchase a desired product. Following this explanation, and after ensuring that the respondents understood the workings of the BDM mechanism, the respondent was 
asked to state a bid for each variety and these bids were written down by the enumerators. After the bidding, the respondent picked one of the two varieties (by picking a slip of paper from a bag containing two slips, each labeled with a different geometric figure). The triangle represented the iron-enriched bean variety and the square represented the local variety but the researchers were the only people who knew this. This selection determined the variety the respondent might end up purchasing. After picking the variety, the respondent picked another slip of paper from a second bag which had 16 slips with prices, ranging from 3.25 Quetzals (Q 3.25) to 7 Quetzals (Q 7), with 0.25 Quetzals (Q 0.25) intervals. Respondents were previously informed about this range. This was the uniform distribution of potential market sale prices that the subject was competing against. It was explained to respondents that if the price picked from this random draw was lower than their initial bid for the bean variety (also randomly picked from the first bag), the respondent could purchase $1 \mathrm{lb}$. of that variety, making an out-of-pocket payment for a price equal to the competing bid. Otherwise, the respondent could not make a purchase.

\section{Survey and other tools}

A lengthy survey was designed in collaboration with local experts and was pretested prior to the data collection. It was divided into three parts, and each part was completed during one of the three visits. In treatment arms, the information about nutrition and other characteristics of the iron-enriched bean variety were given through a recorded (simulated) radio message, which the respondents listened to on individual MP3 devices (see Appendix 1 for the content of this message). Qualitative background studies and literature reviews suggest that a simulated radio message would be the most effective information transmitting mean in the rural Guatemalan context, in which illiteracy rate is traditionally high, especially in indigenous communities, and radio ownership and usage is close to $90 \%$ (Avila 2010). This message on nutrition was recorded in Spanish, using local vocabulary and phrases, and the content of the message was developed and validated by nutritionists and by local leaders. This message included topics related to the agronomic and nutritional characteristics of the IB variety and its potential benefits for children and women's health.

\section{Ethics committee approval and informed consent}

This study was approved by the National Committee of Ethics in Health of the Ministry of Public Health and Social Assistant of Guatemala by Resolution No. 37-13 of May 28/2013.

Informed consent: "Informed consent was obtained from all individual participants included in the study."

\section{Willingness to pay and premium/discount for iron-enriched bean variety}

Figure 1 shows the frequency distribution of the WTP for the traditional and the IB bean varieties. For both varieties, almost half (43.5\%) of the bids were the same as the average observed market price of beans during the survey ( $5 \mathrm{Q} /$ pound). Bids below 5 Q, comprised $43 \%$ and $31.2 \%$ of the bids for the traditional and the iron-enriched varieties, respectively. Furthermore, bids greater than 5 Q comprised 13.4 and $25.3 \%$ of the bids for the traditional and the iron-enriched varieties, respectively. 


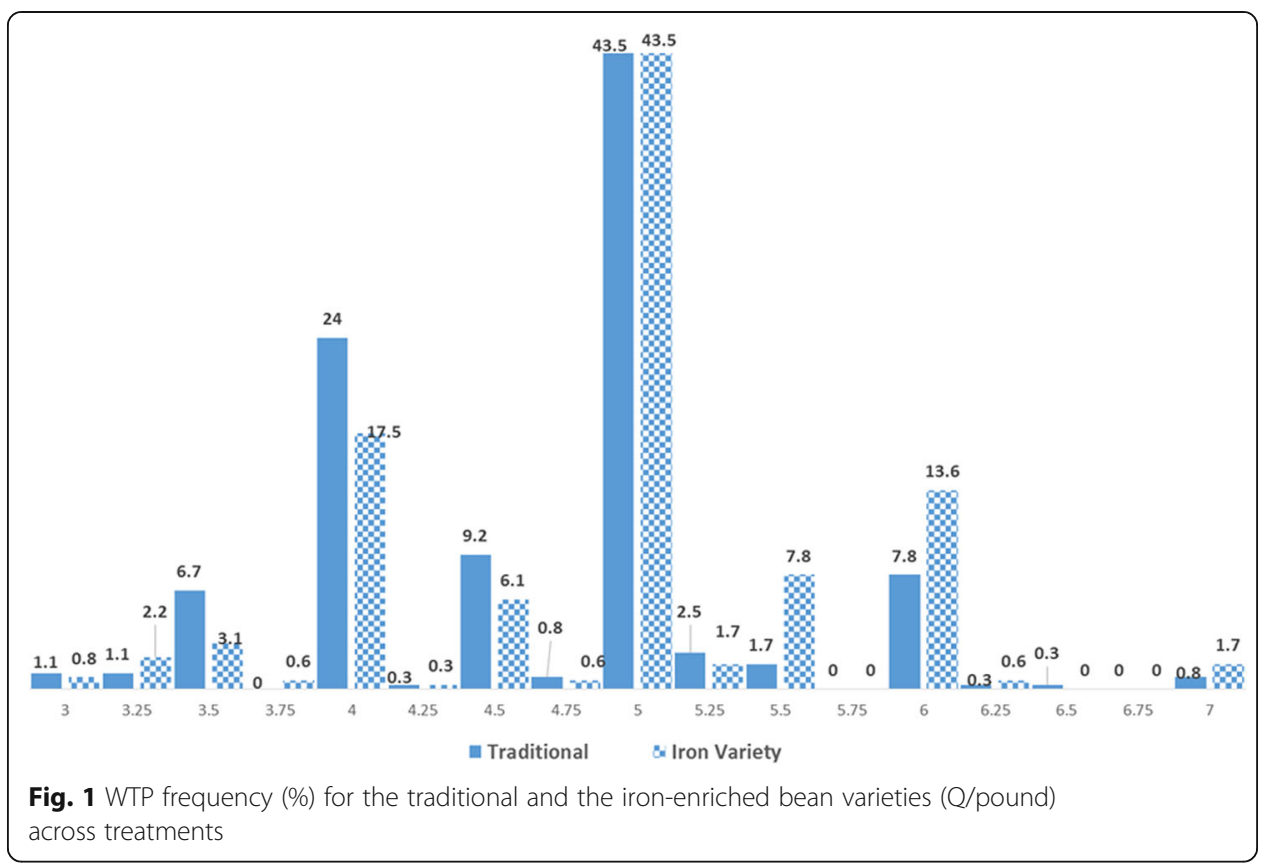

Based on these results, the WTP data can be grouped as follows:

1. WTP_local $=5$ Q; WTP_iron $=5 \mathrm{Q}(15.60 \%)$

2. WTP_local $=5 \mathrm{Q}$ and WTP_iron $\neq 5 \mathrm{Q}(28.13 \%)$

3. WTP_local $\neq 5 \mathrm{Q}$ and WTP_iron $=5 \mathrm{Q}(28.13 \%)$

4. WTP_local $\neq 5 \mathrm{Q}$ and WTP_iron $\neq 5 \mathrm{Q}(28.41 \%)$

For the $15.6 \%$ of respondents in which their bids for both varieties equal $5 \mathrm{Q}$, we can assume that their bids may be censored, i.e., influenced by the price of outside markets. Those stating prices equal to the market price $(5 \mathrm{Q})$ may have had higher WTP due to the perceived transaction costs of obtaining the same product outside the auction but bid the price at which they could buy a product in the market (Banerji et al. 2013) Another reason why bids submitted by the $15.6 \%$ of the respondents could be censored is the nature of the currency interval. The data show that most of the bids were in currency bounds where the majority ranges from $4.5 \mathrm{Q}$ to $5.5 \mathrm{Q}$. As a result, participants' bids could bind between the currency intervals. Therefore, for those who stated $5 \mathrm{Q}$ for both varieties, we can assumed that there bids were interval censored where the lower and upper bounds of WTP were observed instead of the real WTP, such that WTP can be left and/or right censored (Oparinde et al. 2016c).Thus right- and interval-censored models were estimated. The Akaike Information Criteria (AIC) was used to compare both models. The model with the smaller AIC fit the data better than the one with larger AIC (Burnham and Anderson 2002).

Censoring is a feature of the data collection mechanism (Greene 2006) that allows the identification of potential socioeconomic factors generating respondents' censored bids for both varieties. 
As the aim of this study was to measure the premium/discount for the IB variety compared with the local one, this was computed as the difference between WTP for the iron-enriched variety and WTP for the local variety (Eq. 1).

$$
\operatorname{PREM}_{\mathrm{i}, \mathrm{BL}}=\mathrm{WTP}_{\mathrm{i}, \mathrm{B}}-\mathrm{WTP}_{\mathrm{i}, \mathrm{L}}
$$

Where:

$\mathrm{PREM}_{\mathrm{i}, \mathrm{BT}}=$ The WTP a premium of respondent $\mathrm{i}$ for the iron-enriched variety

(B) compared to the local variety $(\mathrm{L})$

$\mathrm{WTP}_{\mathrm{i}, \mathrm{B}}=$ The WTP of respondent i for the iron-enriched variety $(\mathrm{B})$

$\mathrm{WTP}_{\mathrm{i}, \mathrm{L}}=$ The WTP of respondent $\mathrm{i}$ for the traditional variety $(\mathrm{L})$

Figure 2 shows the distribution of differences in WTP for one $1 \mathrm{lb}$. of iron-enriched bean variety in Quetzals $(\mathrm{Q})$ compared to the local bean variety or WTP premium.

As we already know the group into which the WTP premiums fall, but we do not know their real value due the potential censored value of some of the WTP bids, either for one of the varieties or for both, then an interval-censored regression model applies in order to determine the socioeconomic factors affecting the WTP premium.

The interval-censored model states that the probability that the true WTP PREMIUM of a respondent, with characteristics $Y$ lies in the interval $\left[\mathrm{PREM}_{\mathrm{L}}, \mathrm{PREM}_{U}\right]$ is given by $\phi\left(\mathrm{PREM}_{\mathrm{U}} \mid \mathrm{Y}\right)-\phi \phi\left(\mathrm{PREM}_{\mathrm{L}} \mid \mathrm{Y}\right)$, where PREM is assumed to follow a distribution with a standard normal cumulative distribution function $(\phi)$. As the WTP premium is censored because of the WTP censoring, the lower and upper bounds were defined according to WTP premium data. Lower bounds range from -2 to -0.001 and the upper bound from 0 to 2 .

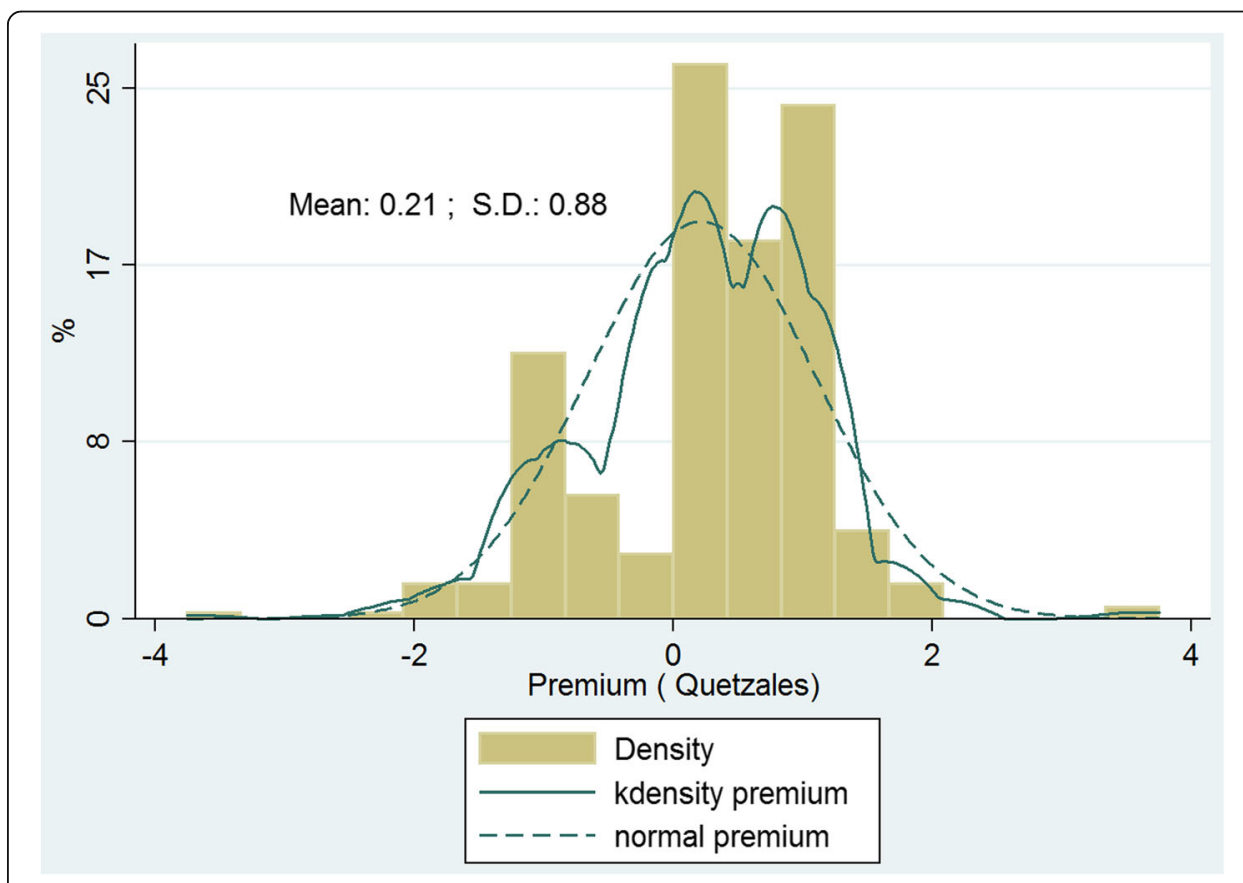

Fig. 2 Distribution of differences in WTP premium for $1 \mathrm{lb}$ of the IB bean variety 
In order to include in the analysis any potential differences in the intervention that could impact on the results (e.g., how the enumerator explained the BDM game, interview time, or any other effect of the repetition process), a random effect model of WTP premium was also estimated. As we have a relatively high number of individuals, we considered the individual differences as random disturbances (Eq. 2) drawn from a specified distribution, including the regressor $(\rho)$ :

$$
\text { PREMi, bt }=\alpha+x \beta+\rho i+\varepsilon t
$$

A Hausman and a Breusch-Pagan Lagrange multiplier (LM) test was run to give more support to the random effect model estimation.

To check the robustness of the random effects absolute WTP premium model and the interval-censored WTP premium model, an ordinary least square model (OLS) was also estimated (Appendix 2).

\section{Independent variables}

Based on previous studies that analyzed consumer acceptance for biofortified crops and the role information played, the following independent variables were included in the models (Table 1).

\section{The progress out of poverty index (PPI)}

The PPI is a poverty measurement tool developed by the Grameen Foundation. It is computed by using the answer to 10 questions about household characteristics and asset ownership, to determine the likelihood that the household is living below the poverty line (US\$ 1.25 / day (2005 PPP)). The PPI is country specific (Grameen Foundation 2015). There is a set of 10 specific questions for 45 countries. In this study, country-specific questions for Guatemala were asked. The higher the PPI, the likelihood of a household to be under the poverty line is lower.

\section{Food frequency index (FFI)}

A FFI was constructed following Arimond and Ruel (2002) with data collected on 15 food groups for a 7-day recall period. Respondents were first asked if they had consumed the food group in the last 7 days, and if yes, how many days in the last 7 days they consumed the food. For each food group, a household or individual receives a score of 0 for frequencies lower than 4 days per week, a score of unity for frequencies from four to six (inclusive) days per week, and a score of two for frequencies of seven or more. The diversity count is then summed across food groups (Smale et al. 2013). With 15 groups, the range of this indicator is considerably big (1 to 30), whereas the maximum FFI in the data is 19.

\section{Information retention index (IRI)}

This index is built and assesses how much of the information received was actually retained by the respondents. A set of questions relating to anemia and iron deficiency were asked the first day to all respondents before the radio message was heard by those in treatments 2 and 3. On day 3, the same set of questions was asked to those who received information once or thrice. One index is built for pre-information, and another one for the post-information given. 
Table 1 Independent variables included in the models used

\begin{tabular}{|c|c|}
\hline Variables & Description \\
\hline Treatment 2 (information once) & $=1$ respondent was in treatment $2 ; 0$ otherwise. \\
\hline Treatment 3 (Information three times) & $=1$ respondent was in treatment 3; 0 otherwise. \\
\hline Variety order & $=1$ if iron variety was received first; 0 otherwise. \\
\hline Gender & $=1$; respondent is male; 0 otherwise. \\
\hline Age & $\begin{array}{l}\text { Continuous variable indicating the age of the } \\
\text { respondent. }\end{array}$ \\
\hline Education & $\begin{array}{l}\text { Categorical variable indicating respondents' } \\
\text { education level. }\end{array}$ \\
\hline $\begin{array}{l}\text { Area planted in } 2013 \\
\text { The household is a bean producer }\end{array}$ & $\begin{array}{l}\text { Square meters planted in total in the farm in } 2013 \text {. } \\
\text { Dummy variable indicating that the respondent } \\
\text { plants beans every year. }\end{array}$ \\
\hline The Progress out of Poverty index (PPI) & $\begin{array}{l}\text { Grameen Foundation's Progress out of Poverty index } \\
\text { (PPI) accounts for head of HH's education, } \mathrm{HH} \text { assets } \\
\text { and income (calculated by the authors with survey } \\
\text { data, explained below). }\end{array}$ \\
\hline Quantity of bean grain at home & $\begin{array}{l}\text { Continuous variable indicating the quantity of bean } \\
\text { grain at home at the time of the visit. }\end{array}$ \\
\hline Monthly expenses & Average $\mathrm{HH}$ monthly expenses. \\
\hline Number of people met & $\begin{array}{l}\text { Continuous variable indicating the number of people } \\
\text { met in the community in the last } 3 \text { days. }\end{array}$ \\
\hline Hear iron food & $\begin{array}{l}\text { Dummy variable indicating if the respondent had } \\
\text { heard about iron in food. }\end{array}$ \\
\hline Food Frequency Index (FFI) & Food Frequency Index, explained below. \\
\hline
\end{tabular}

Each index was constructed using four questions highly related to the information provided in the radio message:

1. Have you heard of anemia before now? Yes $=1$, No $=0$

2. One of the most important symptoms/consequences of anemia is fatigue? Yes $=1$, $\mathrm{No}=0$

3. One of the most important symptoms/consequences of anemia is stunting? Yes = $1, \mathrm{No}=0$

4. Have you heard about iron-enriched food? Yes $=1$, No $=0$

The information retention index (IRI) was estimated as follows:

$$
\mathrm{IRI}=\mathrm{II}_{2}-\mathrm{II}_{1}
$$

where the pre-information index $\left(\mathrm{II}_{1}\right)$ was estimated by adding the different scores obtained in each responses for the former questions during the first day $(\max =4, \min =$ 0 ), and in the same way, the post-information index $\left(\mathrm{II}_{2}\right)$ was estimated using the responses given to the same questions in day 3 .

Then:

IRI $=0$ if the anemia and iron deficiency knowledge stock does not change from day 1 to day 3.

IRI $>0$ if the anemia and iron deficiency knowledge stock increases from day 1 up to day 3.

For those in treatment 1 who did not receive any information, the IRI is considered to be 0 , because any change in their stock of knowledge is not expected as they did not receive any information. Respondents in this treatment were surveyed during the first 
week, and those receiving information were surveyed during the following 2 weeks to avoid information contamination from respondents who received information in the treatments to the ones in the control group; however, some potential contamination can be expected from control to treatments.

\section{Interaction variables}

To analyze the role that gender and educational aspects had on how information affected consumer acceptance, the interaction between the treatment variables, gender and education, were included. Interaction with males (male $\times$ treatment 2 , and male $\times$ treatment 3 ) examined any gender implication and the possible effect of information and repetition on consumer acceptance for the iron-enriched varieties for men and women was also examined, i.e., it is possible that women were more susceptible to nutritional information than men were. The interaction of these treatment variables with education was also included (education $\times$ treatment 2 and education $\times$ treatment 3 ). It was expected that those with higher education would show a stronger effect. Moreover, the effect of the order in which the bean variety was given to respondents was also included. It was expected that those respondents who received information and the iron-enriched bean variety on the second day were willing to pay a higher price for the iron-enriched variety because they had new information in their heads about the benefits of iron-enriched beans.

\section{Results}

\section{Descriptive statistics}

Table 2 presents the key socioeconomic characteristics of the respondents and their households, by treatment arm, and the results of the ANOVA analysis for median homogeneity across the three groups. A pairwise comparison was also carried out using Tukey test to compare the median differences of these characteristics between treatments (treatment 1 vs treatment 2 , treatment 1 vs treatment 3 , and treatment 2 vs treatment 3). The key socioeconomic characteristics listed were those that were hypothesized to affect respondent WTP.

Most of the key participants and households' social and economic characteristics were similar across treatments, revealing that randomization in treatment arms worked well. Statistical differences were observed for gender between all treatments, in the number of members per household and in the percentage of households with children between 1 to 5 years between all treatments according to the Information Retention Index.

Variables such as initial knowledge about iron deficiency and anemia, and the quantity of bean they had at home, were not significantly different across treatments, showing similar iron deficiency and anemia awareness endowment, and levels of product ownership among groups. Information from the National Agricultural Research System (NARS) variable was similar across treatments as well. Similarly, there were no significant differences in the results of the BDM mechanism across treatments. Moreover, $45 \%$ of the respondents "won" in the BDM experiment. Among the "winners," $7.7 \%$ did not want to pay and $10.2 \%$ were unable to pay. On average, $15.2 \%$ of those who won and did not pay stated lack of money as their reason for not paying; this proportion was also statistically similar across treatments. These results are similar to those found in other studies; Oparinde et al. (2016b) stated that 13\% of subjects could be expected 
Table 2 Social and economic characteristics by treatment group (ANOVA test and pairwise comparison)

\begin{tabular}{|c|c|c|c|c|c|c|}
\hline \multirow[t]{2}{*}{ Variable } & \multirow[t]{2}{*}{ Definition } & \multicolumn{3}{|l|}{ Mean (S.D.) } & \multirow[b]{2}{*}{$\begin{array}{l}\text { Prob > } \\
\text { F }\end{array}$} & \multirow[b]{2}{*}{$\begin{array}{l}\text { Tukey } \\
\text { P > t } \\
\text { T1 vs T2 } \\
\text { T1 vs T3 } \\
\text { T2 vs T3 }\end{array}$} \\
\hline & & $\begin{array}{l}\text { Treatment } 1 \\
\text { (no } \\
\text { information) } \\
N=120\end{array}$ & $\begin{array}{l}\text { Treatment } 2 \\
\text { (information } \\
\text { once) } \\
N=120\end{array}$ & $\begin{array}{l}\text { Treatment } 3 \\
\text { (information } \\
\text { three times) } \\
N=119\end{array}$ & & \\
\hline Age & $\begin{array}{l}\text { Respondent's age } \\
\text { (in years) }\end{array}$ & $36.24(11.40)$ & $35.82(11.41)$ & $34.96(34.96)$ & 0.73 & $\begin{array}{l}0.33 \\
0.50 \\
0.18\end{array}$ \\
\hline Male $^{a}$ & $\begin{array}{l}1 \text { if respondent's gender is } \\
\text { male, } 0 \text { otherwise }\end{array}$ & $45.46 \%$ & $23.01 \%$ & $37.23 \%$ & 0.00 & $\begin{array}{l}0.00^{c} \\
0.08^{a} \\
0.03^{b}\end{array}$ \\
\hline Literate & $\begin{array}{l}1 \text { if respondent knows how } \\
\text { to read and write }\end{array}$ & $78.03 \%$ & $76.25 \%$ & $73.00 \%$ & 0.77 & $\begin{array}{l}0.21 \\
0.37 \\
0.15\end{array}$ \\
\hline Household size ${ }^{b}$ & Number of $\mathrm{HH}$ members & $6.32(2.53)$ & $6.06(2.67)$ & $5.46(2.10)$ & 0.02 & $\begin{array}{l}0.33 \\
0.12 \\
0.06^{\mathrm{a}}\end{array}$ \\
\hline Monthly expenditure & $\begin{array}{l}\text { Total expenditures in the } \\
\text { last } 30 \text { days (in Quetzals) }\end{array}$ & $2447(1217)$ & $2629(2179)$ & $2265(1071)$ & 0.20 & $\begin{array}{l}0.19 \\
0.17 \\
0.31\end{array}$ \\
\hline $\begin{array}{l}\text { The Progress out of } \\
\text { Poverty index (PPI) }\end{array}$ & $\begin{array}{l}\text { HH Poverty level according } \\
\text { to Grameen Foundation } \\
\text { Index }\end{array}$ & $60.93 \%$ & $66.47 \%$ & $65.45 \%$ & 0.31 & $\begin{array}{l}0.44 \\
0.27 \\
0.13\end{array}$ \\
\hline $\begin{array}{l}\text { Food Frequency Index } \\
\text { (FFI) }\end{array}$ & $\begin{array}{l}\text { Counting of } 15 \text { food } \\
\text { groups consumed in the } \\
\text { last } 7 \text { days (less than } 4=0 \text {, } \\
4-6=1,7+=2 \text { ) }\end{array}$ & $6.34(3.19)$ & $5.90(2.44)$ & $5.93(2.57)$ & 0.39 & $\begin{array}{l}0.15 \\
0.19 \\
0.20\end{array}$ \\
\hline $\begin{array}{l}\text { Infants under } \\
12 \text { months }\end{array}$ & $\begin{array}{l}\% \mathrm{HHs} \text { with infants less } \\
\text { than } 12 \text { months old }\end{array}$ & $22.51 \%$ & $25.01 \%$ & $20.34 \%$ & 0.40 & $\begin{array}{l}0.13 \\
0.21 \\
0.16\end{array}$ \\
\hline $\begin{array}{l}\text { Children between } 1 \\
\text { and } 5 \text { years old }{ }^{c}\end{array}$ & $\begin{array}{l}\% \mathrm{HH} \text { s with children } \\
\text { between } 1 \text { and } 5 \text { years }\end{array}$ & $53.32 \%$ & $40.03 \%$ & $45.20 \%$ & 0.06 & $\begin{array}{l}0.00^{c} \\
0.07^{a} \\
0.02^{b}\end{array}$ \\
\hline $\begin{array}{l}\text { Quantity of beans at } \\
\text { home }\end{array}$ & $\begin{array}{l}\text { Quantity of beans at home } \\
\text { when the first sample was } \\
\text { delivered (Ibs) }\end{array}$ & 405.95 (486.34) & $326.54(460.39)$ & $343.85(468.32)$ & 0.39 & $\begin{array}{l}0.14 \\
0.14 \\
0.11\end{array}$ \\
\hline Anemia knowledge & $\begin{array}{l}\text { Index describing anemia } \\
\text { knowledge }(\min =0 \\
\max =12)\end{array}$ & $3.48(3.06)$ & $3.56(3.54)$ & $3.76(3.69)$ & 0.81 & $\begin{array}{l}0.18 \\
0.22 \\
0.35\end{array}$ \\
\hline $\begin{array}{l}\text { Information Retention } \\
\text { Index }\end{array}$ & $\begin{array}{l}\text { Information Retention Index } \\
(\min =0, \max =4)\end{array}$ & $0(0)$ & $0.991(0.78)$ & $1.252(1.03)$ & 0.00 & $\begin{array}{l}0.01^{c} \\
0.00^{c} \\
0.09^{a}\end{array}$ \\
\hline Winner & 1 if participant won & $39.10 \%$ & $49.12 \%$ & $47.02 \%$ & 0.26 & $\begin{array}{l}0.20 \\
0.15 \\
0.11\end{array}$ \\
\hline $\begin{array}{l}\text { Won and paid (\% of } \\
\text { those who paid } \\
\text { among winners) }\end{array}$ & $\begin{array}{l}1 \text { if participant won and } \\
\text { paid }\end{array}$ & $63.89 \%$ & $52.56 \%$ & $64.31 \%$ & 0.23 & $\begin{array}{l}0.12 \\
0.11 \\
0.23\end{array}$ \\
\hline $\begin{array}{l}\text { Won and did not pay } \\
\text { (\% of those who did } \\
\text { not pay among } \\
\text { winners) }\end{array}$ & $\begin{array}{l}1 \text { if participant won and } \\
\text { did not pay }\end{array}$ & $17.02 \% \%$ & $23.72 \%$ & $10.70 \%$ & 0.17 & $\begin{array}{l}0.19 \\
0.12 \\
0.27\end{array}$ \\
\hline $\begin{array}{l}\text { Won and could not } \\
\text { pay (\% of those who } \\
\text { could not pay among } \\
\text { winners) }\end{array}$ & $\begin{array}{l}1 \text { if participant won and } \\
\text { could not pay }\end{array}$ & $19.13 \%$ & $23.72 \%$ & $25.01 \%$ & 0.27 & $\begin{array}{l}0.19 \\
0.23 \\
0.12\end{array}$ \\
\hline $\begin{array}{l}\% \text { of those who } \\
\text { stated no money as } \\
\text { reason for no pay }\end{array}$ & $\begin{array}{l}1 \text { if lack of money was the } \\
\text { main reason for no } \\
\text { payment }\end{array}$ & $9.40 \%$ & $10.92 \%$ & $10.92 \%$ & 0.14 & $\begin{array}{l}0.11 \\
0.15 \\
0.11\end{array}$ \\
\hline
\end{tabular}

${ }^{a}$ Statistically different at $10 \%$ significance level

${ }^{\mathrm{b}}$ Statistically different at $5 \%$ significance level

'Statistically different at $1 \%$ significance level 
to be unable to pay out of pocket when conducting auction experiments in developing countries. The inability to make an out-of-pocket payment was correlated with a country's wealth levels, but it varied significantly across countries.

\section{Sensory evaluation}

Table 3 shows the frequency of hedonic ratings of the sensory attributes of the two bean varieties. According to the results of the sensory evaluation, participants scored both varieties above 6 (80\% or more). These results were similar for both varieties in all three treatments and were marginally higher for the iron-enriched variety for all the characteristics evaluated except for cooked bean toughness in treatments 2 and 3. For treatment 1,

Table 3 Frequency of respond for hedonic rating for bean varieties (home testing, northwest Guatemala) (hedonic score/\%)

\begin{tabular}{|c|c|c|c|c|c|c|c|c|}
\hline & $\begin{array}{l}\text { Bean } \\
\text { variety }\end{array}$ & $\begin{array}{l}\text { Raw } \\
\text { bean } \\
\text { color }\end{array}$ & $\begin{array}{l}\text { Raw } \\
\text { bean } \\
\text { size }\end{array}$ & $\begin{array}{l}\text { Bean } \\
\text { taste }\end{array}$ & $\begin{array}{l}\text { Cooking } \\
\text { time }\end{array}$ & $\begin{array}{l}\text { Cooked } \\
\text { bean } \\
\text { thickness }\end{array}$ & $\begin{array}{l}\text { Cooked } \\
\text { bean } \\
\text { toughness }\end{array}$ & Overall \\
\hline \multirow[t]{4}{*}{$\begin{array}{l}\text { Control (T1): No } \\
\text { information } \\
\text { presented }\end{array}$} & Local & $\begin{array}{ll}7 & 60.83 \% \\
6 & 34.17 \% \\
5 & 5.00 \%\end{array}$ & $\begin{array}{l}7 \quad 65.83 \% \\
648.33 \% \\
55.00 \% \\
20.83 \%\end{array}$ & $\begin{array}{l}770.83 \% \\
622.50 \% \\
55.00 \% \\
21.67 \%\end{array}$ & $\begin{array}{l}749.17 \% \\
636.67 \% \\
5 \quad 6.67 \% \\
33.33 \% \\
24.17 \%\end{array}$ & $\begin{array}{l}752.50 \% \\
634.17 \% \\
5 \quad 9.17 \% \\
32.50 \% \\
21.67 \%\end{array}$ & $\begin{array}{l}758.5 \% \\
637.6 \% \\
53.90 \%\end{array}$ & $\begin{array}{ll}7 & 64.17 \% \\
6 & 29.17 \% \\
5 & 4.17 \% \\
4 & 0.83 \% \\
3 & 1.66 \%\end{array}$ \\
\hline & $\mathrm{IB}$ & $\begin{array}{l}772.50 \% \\
621.67 \% \\
54.17 \% \\
31.67 \%\end{array}$ & $\begin{array}{l}769.17 \% \\
625.83 \% \\
53.33 \% \\
40.83 \% \\
30.83 \%\end{array}$ & $\begin{array}{ll}7 & 81.67 \% \\
6 & 16.67 \% \\
5 & 1.67 \%\end{array}$ & $\begin{array}{ll}7 & 68.33 \% \\
6 & 25.00 \% \\
5 & 5.00 \% \\
3 & 1.67 \%\end{array}$ & $\begin{array}{l}775.00 \% \\
618.33 \% \\
55.83 \% \\
30.83 \%\end{array}$ & $\begin{array}{l}770.00 \% \\
6.19 .65 \% \\
57.33 \% \\
43.02 \%\end{array}$ & $\begin{array}{l}7 \text { 77.50\% } \\
620.00 \% \\
5 \text { 1.67\% } \\
40.83 \%\end{array}$ \\
\hline & Difference i & n distributic & & & & & & \\
\hline & $\begin{array}{l}\text { Pearson } \\
\text { Chi-square } \\
\text { ( } p \text { value) }\end{array}$ & 0.17 & 0.12 & $0.08^{a}$ & 0.23 & 0.13 & 0.06 & 0.33 \\
\hline \multirow[t]{4}{*}{$\begin{array}{l}\text { T2: Information } \\
\text { presented once }\end{array}$} & Local & $\begin{array}{l}759.17 \% \\
636.67 \% \\
53.33 \% \\
30.83 \%\end{array}$ & $\begin{array}{l}753.33 \% \\
643.33 \% \\
53.33 \%\end{array}$ & $\begin{array}{l}765.00 \% \\
633.33 \% \\
51.67 \%\end{array}$ & $\begin{array}{l}760.00 \% \\
630.00 \% \\
56.67 \% \\
32.50 \% \\
20.83 \%\end{array}$ & $\begin{array}{l}755.83 \% \\
638.33 \% \\
54.17 \% \\
31.67 \%\end{array}$ & 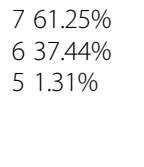 & $\begin{array}{l}764.17 \% \\
632.50 \% \\
52.50 \% \\
30.83 \%\end{array}$ \\
\hline & $\mid \mathrm{B}$ & $\begin{array}{l}7 \quad 79.17 \% \\
619.17 \% \\
51.67 \%\end{array}$ & $\begin{array}{l}775.00 \% \\
624.17 \% \\
50.83 \%\end{array}$ & $\begin{array}{l}787.50 \% \\
610.00 \% \\
52.50 \%\end{array}$ & $\begin{array}{l}7 \quad 74.17 \% \\
620.00 \% \\
54.17 \% \\
31.66 \%\end{array}$ & $\begin{array}{ll}7 & 72.50 \% \\
6 & 24.17 \% \\
5 & 1.67 \% \\
3 & 1.67 \%\end{array}$ & $\begin{array}{l}777.85 \% \\
618.24 \% \\
53.91 \%\end{array}$ & $\begin{array}{l}7 \text { 82.50\% } \\
615.83 \% \\
50.83 \% \\
30.83 \%\end{array}$ \\
\hline & Difference i & n means & & & & & & \\
\hline & $\begin{array}{l}\text { Pearson } \\
\text { Chi-square } \\
\text { ( } p \text { value) }\end{array}$ & $0.07^{\mathrm{a}}$ & $0.06^{a}$ & 0.22 & 0.32 & 0.120 & 0.16 & $0.05^{b}$ \\
\hline \multirow[t]{4}{*}{$\begin{array}{l}\text { T3: Information } \\
\text { presented three } \\
\text { times }\end{array}$} & Local & $\begin{array}{l}759.66 \% \\
636.13 \% \\
54.20 \%\end{array}$ & $\begin{array}{l}756.30 \% \\
641.18 \% \\
52.52 \%\end{array}$ & $\begin{array}{l}7 \quad 66.39 \% \\
631.09 \% \\
52.52 \%\end{array}$ & $\begin{array}{l}747.90 \% \\
645.38 \% \\
55.88 \% \\
35.84 \%\end{array}$ & $\begin{array}{l}756.30 \% \\
641.18 \% \\
52.52 \%\end{array}$ & $\begin{array}{l}753.27 \% \\
631.82 \% \\
510.51 \% \\
44.40 \%\end{array}$ & $\begin{array}{l}758.82 \% \\
638.66 \% \\
52.52 \%\end{array}$ \\
\hline & IB & $\begin{array}{l}7 \quad 80.67 \% \\
615.13 \% \\
54.20 \%\end{array}$ & $\begin{array}{ll}7 & 80.67 \% \\
6 & 16.81 \% \\
5 & 1.68 \% \\
4 & 0.84 \%\end{array}$ & $\begin{array}{l}788.24 \% \\
67.56 \% \\
54.20 \%\end{array}$ & $\begin{array}{ll}7 & 66.39 \% \\
6 & 27.73 \% \\
5 & 5.04 \% \\
1 & 0.84 \%\end{array}$ & $\begin{array}{l}7 \text { 78.99\% } \\
615.97 \% \\
54.20 \% \\
10.84 \%\end{array}$ & $\begin{array}{l}778.83 \% \\
617.28 \% \\
53.89 \%\end{array}$ & $\begin{array}{ll}7 & 84.03 \% \\
6 & 11.76 \% \\
5 & 4.20 \%\end{array}$ \\
\hline & Difference i & n means & & & & & & \\
\hline & $\begin{array}{l}\text { IB vs. } \\
\text { Local }\end{array}$ & $0.02^{b}$ & $0.07^{a}$ & $0.09^{a}$ & 0.23 & $0.01^{b}$ & 0.11 & $0.09^{\mathrm{a}}$ \\
\hline
\end{tabular}

${ }^{a}$ Statistically different at $10 \%$ significance level

${ }^{b}$ Statistically different at $5 \%$ significance level

'Statistically different at $1 \%$ significance level 
the liking scores distribution was statistically different between the traditional and iron-enriched variety in the case of taste, showing that for an iron-enriched variety, almost all of the respondents were in groups 6 and 7. For Treatment 2, the liking distribution was statistically different for color, size, and the overall evaluation, while for treatment 3 , taste and toughness were the only two attributes that showed any differences between the two varieties. In all these cases, a higher proportion of respondents were grouped in 6 and 7 scale for the iron-enriched variety compared to the traditional one.

\section{Economic evaluation}

Table 4 shows the mean WTP results for the two bean types. According to these results, the average WTP for the IB variety is marginally higher in all three treatments, although these differences between the WTP for the IB variety compared to the traditional variety are not statistically significant either across or within the three treatments. Therefore, consumers value both varieties equally, and the presence of information and the frequency in which it was received did not have a significant impact on consumers' WTP. Those results are in contrast to those obtained by Oparinde et al. (2016c) who found that information had a significantly positive effect on WTP premium and that providing the nutrition information (loss frame) three times versus once significantly increased consumer demand for the WIB variety.

\section{Econometric analysis}

Determinants of premium for the iron-enriched bean variety

To identify which econometric approach should be used, a Hausman test was run to accept or reject the null hypothesis that the preferred model had random effects or

Table 4 Mean WTP for bean varieties

\begin{tabular}{ll}
\hline Variety & Average WTP \pm S.D. (Quetzals) \\
\hline Iron biofortified variety ("super chiva") & $4.83 \pm 0.71$ \\
IB (T1) & $4.96 \pm 0.83$ \\
IB (T2) & $4.89 \pm 0.76$ \\
IB (T3) & \\
Traditional variety ("parramos") & $4.70 \pm 0.72$ \\
Traditional (T1) & $4.67 \pm 0.74$ \\
Traditional (T2) & $4.67 \pm 0.71$ \\
Traditional (T3) & Premium/discount \\
& \\
Within treatment comparison (\% difference) & $2.76 \%$ \\
T1 (IB vs. Traditional) & $6.20 \%$ \\
T2 (IB vs. Traditional) & $4.71 \%$ \\
T3 (IB vs. Traditional) & $-2.62 \%$ \\
Across treatment comparison. WTP premium = IB - Traditional (\% difference) \\
T1 vs. T2 \\
T1 vs. T3 \\
T2 vs. T3
\end{tabular}

Average market price: $5 \mathrm{Q} /$ pound 
fixed effects. It tested whether the unique error $\left(\mu_{\mathrm{i}}\right)$ was correlated with the regressor, and the null hypothesis showed they are not (Torres-Reyna 2007). With a Prob > chi2 $=0.6990$, random effects were used.

A Breusch-Pagan Lagrange multiplier test was also run to decide between random effects regression and a simple OLS regression. With a prob $>$ chibar $2=0.00$, the null hypothesis that states that variances across entities are zero was rejected; then, random effects was appropriate in this case. An OLS model was also estimated to check the robustness of the results, but its results are not presented because the model was not significant.

The results of regression models estimating the effects of information and its repetition on participant premiums for the iron-enriched bean are presented in Table 5. Socioeconomic variables and cross terms are only included in cases where these variables are not strongly correlated, to avoid potential multicollinearity issues. Model 1 is the random effects, and models 2 and 3 are the right-censored and interval-censored ones. Robust standard errors are reported for all models. Coefficients are compared across models, and models are compared using $R^{2}$ as a measure of goodness-of-fit. For the right- and interval-censored model, squared multiple correlations were computed $\left(R^{2}\right.$ equivalent) between predicted and observed values of premium to compare this model with the random effects estimations. In all cases, partial models were estimated, the first one controlled for the treatment variables (Information and repetition); the second controlled for treatment and socioeconomic characteristics; the third one controlled for interaction variables; and the fourth and last controlled for all variables (full-sample models), interactions included. Full-sample models performed better than the partial-sample models (higher $R^{2}$ ); thus, the latter were not reported. To compare between the full right- and interval-censored models, Akaike information criteria (AIC) are shown. Models with the lowest Akaike (AIC) gave better predictions.

Among the three sample models, the $R^{2}$ was not significantly different, 0.14 in model 1 and 0.13 in models 2 and 3. Since the AIC for model 2 (right censored) was lower than for model 3 (interval censored), model 2 predicted better. Based on those results, we choose to focus our analysis and discussion on model 2, with some references to results in models 2 and 3 whose results are similar.

In model 2, information once and variety delivery order played an important role in WTP premium determination, showing that the role of information depended on the variety delivery order. When the IB variety and nutritional information were delivered on the first day, the WTP premium was 0.5 Q; this premium was almost $80 \%$ higher than those receiving the IB variety on the first day but without any nutritional information. For those receiving the local variety and nutritional information on the first day, the WTP premium was $65 \%$ higher compared to those who received nutritional information and the IB variety on the first day. Those differences were large and significant at $1 \%$. Those results show that the impact of information depends on the order of the variety delivery. It is possible that respondents associated the information they received with the variety that was delivered the same day, even if they had previously been informed about which variety was delivered on that day. Although the first difference in WTP premium (80\%) was higher than the second one (65\%), this implies that nutritional information had a positive and significant impact on WTP premium of $15 \%$ regardless of the delivery order. For educated respondents, with higher IRI, receiving the IB variety first and nutritional information once the WTP premium was $38 \%$ higher 
Table 5 Determinants of WTP premium for the iron-enriched bean variety in Guatemala-random effects model, right-censored model and interval-censored model

\begin{tabular}{|c|c|c|c|}
\hline & $\begin{array}{l}\text { Random effect } \\
\text { model (1) }\end{array}$ & $\begin{array}{l}\text { Right censored model } \\
\text { (Tobit) (2) }\end{array}$ & $\begin{array}{l}\text { Interval censored } \\
\text { model (3) }\end{array}$ \\
\hline Information once & $0.36(0.29)$ & $0.94^{* * *}(0.57)$ & $0.41^{* *}(0.17)$ \\
\hline Information repetition & $-1.17(0.20)$ & $-0.10(0.40)$ & $0.18(0.15)$ \\
\hline Variety delivery order & $-0.28^{* *}(0.12)$ & $-0.49 * *(0.0 .24)$ & $-0.43^{* *}(0.17)$ \\
\hline Men $\times$ information once & $0.07(0.27)$ & $0.02(0.55)$ & $0.43(0.30)$ \\
\hline Men $\times$ Information repetition & $0.38^{* *}(0.16)$ & $0.80^{* * *}(0.29)$ & $0.35(0.26)$ \\
\hline $\mid \mathrm{RI} \times$ information once & $-0.26^{* *}(0.12)$ & $-0.43^{*}(0.23)$ & $-0.12(0.12)$ \\
\hline $\mid \mathrm{RI} \times$ Information repetition & $0.13^{* * *}(0.04)$ & $0.18^{* *}(0.09)$ & $-0.11(0.09)$ \\
\hline Education $\times$ information once & $-0.04(0.03)$ & $-0.18^{* * *}(0.07)$ & $-0.04(0.03)$ \\
\hline Education $\times$ information repetition & $0.05(0.03)$ & $0.08(0.07)$ & $-0.02(0.03)$ \\
\hline Variety delivery order $\times$ information once & $0.53^{* *}(0.22)$ & $0.05^{* *}(0.04)$ & $0.62^{* *}(0.24)$ \\
\hline $\begin{array}{l}\text { Variety delivery order } \times \text { information } \\
\text { repetition }\end{array}$ & $-0.00(0.00)$ & $-0.02(0.01)$ & $0.32(0.26)$ \\
\hline Male & $0.03(0.16)$ & $0.23(0.31)$ & $-0.27(0.19)$ \\
\hline Age & $-0.00(0.00)$ & $-0.02 * * *(0.01)$ & $-0.01^{* *}(0.00)$ \\
\hline Area planted with beans in 2013 & $0.00^{* * *}(0.00)$ & $0.00^{* * *}(0.00)$ & $0.00(0.00)$ \\
\hline Produce beans frequently & $-0.07(0.12)$ & $-0.28(0.25)$ & $0.03(0.12)$ \\
\hline Amount of beans stored at home & $0.00(0.00)$ & $0.02^{* *}(0.01)$ & $0.00(0.00)$ \\
\hline Purchase beans frequently & $-0.02(0.05)$ & $0.05(0.11)$ & $-0.01(0.03)$ \\
\hline Consume beans frequently & $-0.00(0.03)$ & $0.00^{*}(0.07)$ & $0.04(0.02)$ \\
\hline Poverty index & $0.04(0.11)$ & $0.31(0.22)$ & $0.37^{*}(0.21)$ \\
\hline Food frequency index & $-0.00^{* * *}(0.00)$ & $-0.02^{* * *}(0.01)$ & $-0.00(0.00)$ \\
\hline Monthly expenses & $0.00(0.00)$ & $0.00(0.00)$ & $0.00(0.05)$ \\
\hline Have met any people in the community & $0.02(0.05)$ & $0.07(0.10)$ & $-0.21(0.15)$ \\
\hline Have heard about iron in food & $-0.22(0.15)$ & $-0.40(0.30)$ & $0.45(0.36)$ \\
\hline _cons & $0.39(0.34)$ & $1.66^{* *}(0.70)$ & $-0.05(0.04)$ \\
\hline N & 359 & 359 & 359 \\
\hline $\begin{array}{l}\text { Likelihood-ratio test for heteroscedasticity } \\
\text { (Prob > chi2) }\end{array}$ & 0.14 & 0.23 & 0.18 \\
\hline F statistic/Chi ${ }^{2}$ & 0.00 & 0.00 & 0.00 \\
\hline Prob $>$ F/Prob $>C h i^{2}$ & 89.52 & 106.07 & 30.53 \\
\hline$R$-squared & 0.14 & 0.13 & 0.13 \\
\hline $\mathrm{AIC}$ & & 1350 & 1420 \\
\hline
\end{tabular}

Standard errors in parentheses

${ }^{*} p<0.10,{ }^{* *} p<0.05,{ }^{* * *} p<0.01$

than those with similar characteristics but without information. These results are similar for models 1 and 3 .

According to models 1 and 2, the WTP premium for men receiving nutritional information on three separate occasions was lower than for women. Those results can be explained in terms of differences in information processing between men and women. Putrevu et al. (2017) stated that women might benefit more from verbally descriptive messages and men would more from nonverbal reinforcement, e.g., pictures and music. Women seem to have memory advantages for visual and verbal stimuli in advertisements compared to men who might require nonverbal reinforcement of the verbal product 
information (Edens and McCormick 2001). According to Arganini et al. (2012), men usually show skepticism and resistance to nutritional messages especially in less educated and wealthier groups. A higher WTP premium was expected for wealthier men who received information reinforcement. For men with higher IRI and who received repeated nutritional information, the WTP premium was $72 \%$ lower than for women with similar characteristics. Similarly, the effect of nutritional information repetition was $18 \%$ higher for those with high IRI than for those with lower values in this index. This shows that information repetition was effective in this population but information delivered just once was not effective. When nutritional information was given once for those with high IRI, the WTP premium was lower. Those results indicate that respondents may not have understood the information and information enforcement may have helped to iron out any misunderstandings. Respondents also tended to link the nutritional information they received with the bean variety they received on the same day although they were not told which variety they were actually receiving and they may have received a traditional variety which did not have any additional nutritional benefits. The low nutritional and socioeconomic status of most of the respondents might explain this behavior. In addition, the message was transmitted in Spanish (which they spoke), but Mam, not Spanish, is their native/ mother tongue. Some misunderstanding could have been generated because of the choice of language used.

Older respondents and those with higher FFI had a lower WTP premium than those with opposite characteristics. Older respondents are usually less willing to try new things, especially those whose benefits are not visible immediately. And those with high FFI probably thought that they had a good diet and their nutritional requirements were completely filled. Those planting and consuming beans and with grain stored at home had a marginal higher but positive WTP premium than others. It may be related to their tradition of producing or consuming beans, which determine their diets and livelihoods.

\section{Conclusions and discussion}

The aim of this study was to investigate the consumer acceptance of an iron-enriched bean (IB) variety ("super-chiva") compared to a popular traditional local bean variety ("parramos") in northwest Guatemala.

We tested the impact of nutrition information of the IB variety and the impact the frequency with which such information is provided on consumer acceptance. We have collected both sensory evaluation data using hedonic rating methods and economic evaluation data using a BDM auction mechanism. The data was collected using the HUT approach, and a total of 360 households took part in this study. In each household, the principal respondent was the main decision-maker on bean consumption and purchase decisions. One third of these households were asked to evaluate the two bean varieties without receiving any information on the nutritional benefits of the IB variety (control group-treatment 1), one third received information through simulated radio messaging (treatment 2), and one third received the information three times-once every day during the duration of the experiment (treatment 3 ).

Sensory evaluation data revealed significant differences for only some of the bean attributes investigated. Among those that did not receive information (treatment 1 -control group), significant differences were found between the two varieties' cooking time and cooked bean thickness. In the information treatments (2 and 3), significant 
differences were found for raw bean color, raw bean size, bean taste, and cooking time. In all cases, the IB variety was rated higher. The WTP values stemming from the BDM mechanism were however not statistically significantly different for the two bean types, either across or within treatments, although average WTP values for the IB variety were higher in each treatment.

Based on these results, it is expected that consumers liked the IB variety as much as the traditional bean variety. Although respondents rated the IB variety higher in general, the sensory evaluation revealed a marginal (though not statistically significant) premium, and therefore, we cannot conclude that the IB variety is preferred over the local one in this context. Notwithstanding the insignificant differences, the possible respondent- and household-level variables that may affect the magnitude of the WTP premium were investigated using interval-censored, right-censored, and random effects estimation methods. More than $15 \%$ of the bids for both iron-enriched and local varieties were censored at market price level for both varieties. As the respondents were given explanations about the implications of bidding a low or a high WTP, most of them bid the median (50 percentile) of the uniform distribution of potential market sale prices that they were competing against. This was done to reduce the risk of paying more than their real WTP, or losing out an opportunity to purchase a desired bean variety. The respondents with higher social interaction and higher education or income (welfare) made a uniform distribution of risks and probabilities. Further, an analysis using participation bids at the beginning of the experiments was done to validate if this method reduced the percentage of censored bids.

The results showed that nutritional information delivered once had a positive impact on WTP premium for the iron-enriched variety, but this is reforced when the IB variety and the information were given on the same day. The order in which the varieties were deliveried had a significant effect on WTP premium as respondents tended to associate the variety they received with the message they heard on the same day. The order in which the variety was tested is likely to affect the WTP results. A randomization on the day in which respondents in this group would receive the nutritional information might help to overcome this issue. A reinforcement on which variety they are actually receiving each day might also help. Another important finding was that there was a lack of understanding from respondents who might have needed information reinforcement, as it was evident that that nutritional information had a lower impact when it was given once to more educated or respondents with a higher retention index while the impact was higher with repetition in these groups. The language used in the message and the socioeconomic status of the respondents might be related to this behavior. Trying different alternatives to delivering the message (i.e. something more visual or as a video) and using the local language (Mam) should be tested in future research studies.

Information repetition mattered when men received it, especially men with high IRI. Men might require verbal reinforcement of the product information. According to Oparinde et al. (2016c), the frequency of providing the information matters if the information is of loss frame, suggesting the existence of loss aversion in participants' demand for the iron-enriched bean varieties. Possible information contamination or inadequate messaging may be potential causes. Further consumer acceptance studies in Guatemala should test the role that loss frame information might play and how its repetition could impact on WTP for the iron-enriched bean variety. 
This study has shown that preference elicitation experiments' context could also generate bias through the subject's submission of censored bids. Aspects such as social interaction, level of education, income, and other welfare indicators could be related to the potential bias generated. Further research should be done to evaluate the potential role that the out-of-pocket payment may have on this bias.

These results were significant for future research on consumer acceptance of biofortified crops to avoid potential biases and to generate more accurate estimates for the WTP for the varieties evaluated. Results related to the role of nutritional information and its repetition should be taken into account for biofortified crops' dissemination strategy in order to potentiate their adoption in target populations and increase their impact in reducing micronutrient deficiencies mainly in rural populations. This also applies to population segmentation based on welfare or gender characteristics, as they should also be taken into consideration.

\section{Endnotes}

${ }^{1} 1$ USD $=7.67$ Quetzales. July 2013

${ }^{2} 1$ pound $(\mathrm{lb})=0.46 \mathrm{~kg}$

\section{Appendix 1}

Radio message

Speakers:

$\mathrm{W}($ woman $)=$ Mrs. Rosa

$\mathrm{M}(\operatorname{man})=$ Chepe

M: Good morning Mrs. Rosa, are you coming from the market where you did your shopping?

W: Hi, yes, I bought beans among other things for today's lunch.

M: Alright Mrs. Rosa, then you have everything ready to cook your awesome refried beans, just like you know how to make them.

W: Yes indeed Chepe, and these are going to be even better!

M: And why is that Mrs. Rosa?

W: Well, because these beans are different.

M: What do you mean by different? If I see correctly, they are the same as the ones we have always harvested or got at the market.

W: Well yes Chepe, on the outside they look alike but the difference is inside. They have more nutritional value.

M: How is that Mrs. Rosa?

W: A group of experts put together the best characteristics of different types of beans and developed this iron-enriched bean. It is similar to the one we have always eaten but with more iron.

M: And having more iron, what is it useful for Mrs. Rosa?

W: What do you mean by that what is it useful for, Chepe? You work so much from Sunday to Sunday, you have a small son that barely crawls and another one on the way as your wife is pregnant, and you don't know what iron is, and what does it work for? Well, you are certainly careless!

M: Well, no Mrs. Rosa, you know that for those kinds of things, I'm not very knowledgeable. 
W: Alright... you see Chepe, iron is like a vitamin that works to prevent anemia, let's say, it's going to help you feel stronger because it gives strength to your blood. It also helps small children develop healthy, and to concentrate and learn more at school. This means that iron-enriched beans helps nourish the brain when it's growing. The soup helps, but is not as potent as the bean.

M: Oh, I get it Mrs. Rosa, then, it works like the so-called iron sulfate that is given to the small children and the pregnant women at the health center and the clinics in town?

W: Yes Chepe, those products also have iron, but the flavors they sometimes have, don't allow us to drink it, and besides, they don't have the same amount of iron that the bean I'm talking about has.

M: Well, that sounds very good Mrs. Rosa. Listen Mrs. Rosa, and those beans won't taste different or will be harder because of the iron?

W: You see Chepe, I bought these beans from Mr. Juanito from the corner store. He planted them in his plot and told me that there is no difference from the beans we eat here daily. Moreover, his wife has prepared some and says there is no difference. He also says that he plants and cultivates them like the others, they don't need more fertilizer or special care, and they give equal pay or more than the other beans.

M: I believe that's nonsense Mrs. Rosa.

W: Chepito, if you want to, come along to my house for lunch and you can try them, then you will know for yourself....even more, bring along your boy and your wife, they will benefit mostly from this. Don't you see that iron also helps pregnant women to be stronger and have healthier pregnancies, helping at the same time the good development of the baby.

M: Listen Mrs. Rosa, I accept your invitation with pleasure. Besides, you cook very well. Those beans with more iron content sounds good.

W: There you go Chepe. I will then wait for you and your family later.

M: Well Mrs. Rosa, I will see you later. Thank you very much.

W: You are welcome Chepe, have a good day.

M: Have a good day Mrs. Rosa.

\section{Appendix 2}

Table 6 Premium (WTP) for the iron bean variety in Guatemala (Ordinary least square model (OLS) results)

\begin{tabular}{|c|c|c|c|c|c|}
\hline $\begin{array}{l}\text { Dependent variable: WTP } \\
\text { premium }\end{array}$ & $\begin{array}{l}\text { Treatment } \\
\text { effect }\end{array}$ & $\begin{array}{l}\text { Variable } \\
\text { order } \\
\text { effect }\end{array}$ & $\begin{array}{l}\text { Interaction } \\
\text { variables } \\
\text { effect }\end{array}$ & $\begin{array}{l}\text { Socioeconomic } \\
\text { variables effect }\end{array}$ & $\begin{array}{l}\text { Socioeconomic and } \\
\text { interaction variables } \\
\text { effect }\end{array}$ \\
\hline Information once & $\begin{array}{l}0.150 \\
(0.115)\end{array}$ & $\begin{array}{l}0.164 \\
(0.116)\end{array}$ & & $0.267^{*}(0.136)$ & \\
\hline Information repetition & $\begin{array}{l}0.081 \\
(0.115)\end{array}$ & $\begin{array}{l}0.067 \\
(0.116)\end{array}$ & & $0.105(0.121)$ & \\
\hline Variety delivery order & & $\begin{array}{l}-0.080 \\
(0.098)\end{array}$ & & & \\
\hline Men $x$ information once & & & $0.135(0.190)$ & & $0.368(0.238)$ \\
\hline $\begin{array}{l}\text { Men } x \text { Information } \\
\text { repetition }\end{array}$ & & & $0.174(0.168)$ & & $0.384^{*}(0.222)$ \\
\hline IRI $x$ Information once & & & $-0.130(0.094)$ & & $-0.124(0.098)$ \\
\hline $\begin{array}{l}\mid \mathrm{RI} \times \operatorname{Information} \\
\text { repetition }\end{array}$ & & & $-0.091(0.069)$ & & $-0.081(0.073)$ \\
\hline
\end{tabular}


Table 6 Premium (WTP) for the iron bean variety in Guatemala (Ordinary least square model (OLS) results) (Continued)

\begin{tabular}{|c|c|c|c|c|c|}
\hline $\begin{array}{l}\text { Dependent variable: WTP } \\
\text { premium }\end{array}$ & $\begin{array}{l}\text { Treatment } \\
\text { effect }\end{array}$ & $\begin{array}{l}\text { Variable } \\
\text { order } \\
\text { effect }\end{array}$ & $\begin{array}{l}\text { Interaction } \\
\text { variables } \\
\text { effect }\end{array}$ & $\begin{array}{l}\text { Socioeconomic } \\
\text { variables effect }\end{array}$ & $\begin{array}{l}\text { Socioeconomic and } \\
\text { interaction variables } \\
\text { effect }\end{array}$ \\
\hline $\begin{array}{l}\text { Education } x \text { Information } \\
\text { once }\end{array}$ & & & $0.001(0.024)$ & & $-0.015(0.026)$ \\
\hline $\begin{array}{l}\text { Education } x \text { Information } \\
\text { repetition }\end{array}$ & & & $-0.001(0.025)$ & & $-0.018(0.027)$ \\
\hline $\begin{array}{l}\text { Variety delivery order } x \\
\text { information once }\end{array}$ & & & $0.206(0.145)$ & & $0.208(0.152)$ \\
\hline $\begin{array}{l}\text { Variety delivery order } x \\
\text { information repetition }\end{array}$ & & & $0.009(0.170)$ & & $0.007(0.174)$ \\
\hline Male & & & & $0.037(0.107)$ & $-0.243(0.154)$ \\
\hline Age & & & & $-0.009^{* *}(0.004)$ & $-0.009^{* *}(0.004)$ \\
\hline $\begin{array}{l}\text { Area planted with beans } \\
\text { in } 2013\end{array}$ & & & & $0.000^{*}(0.000)$ & $0.000^{*}(0.000)$ \\
\hline Produce bean frequently & & & & $0.024(0.097)$ & 0.007 (0.099) \\
\hline $\begin{array}{l}\text { Among of bean stored } \\
\text { at home }\end{array}$ & & & & $0.004(0.003)$ & $0.004(0.003)$ \\
\hline Purchase bean frequently & & & & $0.275^{* * *}(0.100)$ & \\
\hline $\begin{array}{l}\text { Consume beans } \\
\text { frequently }\end{array}$ & & & & $-0.016(0.029)$ & $-0.016(0.030)$ \\
\hline Poverty Index & & & & $0.312^{*}(0.173)$ & $0.255(0.175)$ \\
\hline Food Frecuency Index & & & & $0.028(0.019)$ & $0.023(0.020)$ \\
\hline Monthly expenses & & & & $-0.000(0.000)$ & $-0.000(0.000)$ \\
\hline $\begin{array}{l}\text { Have met any people in } \\
\text { the community }\end{array}$ & & & & $0.010(0.043)$ & $0.003(0.044)$ \\
\hline $\begin{array}{l}\text { Having heard about iron } \\
\text { in food }\end{array}$ & & & & $-0.296^{* *}(0.126)$ & $-0.152(0.125)$ \\
\hline _cons & $\begin{array}{l}0.140^{*} \\
(0.081)\end{array}$ & $\begin{array}{l}0.179^{*} \\
(0.094)\end{array}$ & $\begin{array}{l}0.218^{* * *} \\
(0.069)\end{array}$ & $0.067(0.278)$ & $0.358(0.279)$ \\
\hline N & 359 & 359 & 359 & 359 & 359 \\
\hline$R^{2}$ & 0.005 & 0.007 & 0.018 & 0.063 & 0.067 \\
\hline $\mathrm{R}^{2}$ Adj. & -0.001 & -0.002 & -0.004 & 0.028 & 0.019 \\
\hline Prob $>F$ & 0.425 & 0.498 & 0.592 & 0.040 & 0.239 \\
\hline $\begin{array}{l}\text { Breusch-Pagan Cook- } \\
\text { Weisberg test } \\
\text { (Prob>chi2) }\end{array}$ & 0.60 & 0.85 & 0.65 & 0.000 & 0.001 \\
\hline White test (Prob>chi2) & 0.47 & 0.67 & 0.99 & 0.834 & 0.839 \\
\hline Test of Ramsey (Prob>F) & - & 0.28 & 0.37 & 0.172 & 0.831 \\
\hline
\end{tabular}




\section{Acknowledgements}

We would like to thank Prof. Jason Lusk for his valuable comments and suggestions during his review of the first draft of this paper. Thanks also to HarvestPlus for providing the funding and to the reviewers for their valuable contributions.

\section{Authors' contributions}

SP participed in the design and coordination of this study, made the data collection and analysis and drafted the manuscript. AO conceived of the study and design. participated on paper writing. EB participated on the design of the study and coordination. CG and MZ participated in the coordination and paper writing. All authors read and approved the final manuscript.

\section{Ethics approval and consent to participate}

All procedures performed in studies involving human participants were in accordance with the ethical standards of the institutional and/or national research committee and with the 1964 Helsinki declaration and its later amendments or comparable ethical standards.

\section{Competing interests}

The authors declare that they have no competing interests.

\section{Publisher's Note}

Springer Nature remains neutral with regard to jurisdictional claims in published maps and institutional affiliations.

\section{Author details}

${ }^{1}$ Centro Internacional de Agricultura Tropical (CIAT), Cali, Colombia. ${ }^{2}$ International Food Policy Research Institute (IFPRI), Washington D.C, USA. ${ }^{3}$ University of Hohenheim, Stuttgart, Germany.

Received: 18 July 2017 Accepted: 29 June 2018

Published online: 25 July 2018

\section{References}

Arganini C, Saba A, Comitato R, Virgili F, Turrini A (2012) Gender differences in food choice and dietary intake in modern Western societies. Public Health - Soc Behav Health 4:83-102

Arimond M, Ruel MT (2002) Progress in developing an infant and child feeding index: an example using the Ethiopia Demographic and Health Survey 2000. International Food Policy Research Institute, Washington DC. Discussion Paper, $\mathrm{p} 143$

Avila R (2010) Financially viable media in emerging and developing markets. World Association of Newspapers and News Publishers Projects (WAN-IFRA), Guatemala, pp 65-75

Banerii, A., Birol, E., Karandikar, B. and Rampal, J. (2015). Information, branding, certification, and consumer willingness to pay for high-iron pearl millet: evidence from experimental auctions in Maharashtra, India. HarvestPlus Working Paper No. 17

Banerij, A., Cowhury, S., De Groote, H., Meenakshi, J.., Haleegoah, J. and Ewool, M. (2013). Using elicitation mechanism to estimate the demand for nutritious maize: evidence from experiments in rural Ghana. HarvestPlus Working Paper No. 10

Burnham KP, Anderson DR (2002) Model selection and inference: a practical information theoretic approach, 2nd edn Springer-Verlag, New York

Chowdhury S, Meenakshi JV, Tomlins K, Owori C (2011) Are consumers willing to pay more for biofortified foods? Evidence from a field experiment in Uganda. Am J Agric Econ 93(1):83-97

Corrigan JR, Rousu M (2006) The effect of initial endowments in experimental auctions. Am J Agric Econ 88(2):448-457

De Groote H, Chege S, Morawtez U (2011) Estimating consumer willingness to pay for food quality with experimental auctions: the case of yellow versus fortified maize meal in Kenya. Agric Econ 42:1-16

de Guatemala G (2012) Plan hambre cero. Ministerio de Salud Pública y Asistencia Social, Gobierno de Guatemala

Edens KM, McCormick CB (2001) How do adolescents process advertisements? The influence of ad characteristics, processing objective, and gender. Contemp Educ Psychol 25:450-463

Grameen Foundation. 2015 Progress out of poverty (PPI). Available from https:/www.povertyindex.org/.

Greene W (2006) Censored data and truncated distributions. In: Mills T, Patterson K (eds) Palgrave handbook of econometrics, vol 1. Palgrave Macmillan, Basingstoke

INE (Instituto Nacional de Estadística) (2006) Encuesta Nacional de Condiciones de Vida (ENCOVI). Instituto Nacional de Estadistica, Guatemala

Loureiro ML, Umberger WJ, Hine S (2003) Testing the initial endowment effect in experimental auctions. Appl Econ Lett 10:271-275

Lusk JL, Shogren JF (2007) Experimental auctions: methods and applications in economics and marketing research. Cambridge University Press, Cambridge

Meenakshi JV, Banerji A, Manyong V, Tomlins K, Mittal N, Hamukwala P (2012) Using a discrete choice experiment to elicit the demand for a nutritious food: willingness to pay for orange maize in rural Zambia. J Health Econ 31:62-71

Morawetz UB, De Groote H, Kimenju SC (2011) Improving the use of experimental auctions in Africa: theory and evidence. J Agric Resour Econ 36(2):263-279

MSPS (Ministerio de Salud Pública y Asistencia Social) (2012) Encuesta Nacional de micronutrientes 2009-2010. Ministerio de Salud Pública y Asistencia Social, Gobierno de Guatemala

Naico ATA, Lusk J (2010) The value of a nutritionally enhanced staple crop: results from a choice experiment conducted with orange-fleshed sweet potatoes in Mozambique. J Afr Econ 19(4):536-558

Oparinde A, Banerij A, Birol E, llona P (2016a) Information and consumer willingness to pay for biofortified yellow cassava: evidence from experimental auctions in Nigeria. Agric Econ 47(2):215-233 
Oparinde, A., Birol, E., Banerji, A. and Perez, S. (2016b). Identifying hypothetical bias in experimental auctions in field settings in developing countries. Presented at 5th International Conference of the African Association of Agricultural Economists, 23-26 September 2016, Addis Ababa, Ethiopia

Oparinde A, Birol E, Murekezi A, Katsvairo L, Diressie M, Nkundimana J, Butare L (2016c) Radio messaging frequency, information framing, and consumer willingness to pay for biofortified iron-enriched beans: evidence from revealed preference elicitation in rural Rwanda. Can J Agric Econ 64(4):613-652

Putrevu S, Gentry J, Fischer E (2001) Exploring the origins and information processing differences between men and women: implications for advertisers. Acad Mark Sci Rev 10:1-14

Saltzman A, Birol E, Bouis H, Boy E, De Moura F, Islam Y, Pfeiffer W (2013) Biofortification: progress toward a more nourishing future. Glob Food Sec 2(1):9-17

Smale, M., Moursi, M., Birol, E. and De Groote, H. (2013). Hybrid seed use and diversity of diets among women in smallholder maize-growing households in Zambia. HarvestPlus Working Paper No. 12

Torres-Reyna, O. (2007). Panel data analysis. fixed and random effects using Stata (v. 4.2). Data \& Statistical Services. Princeton University. Available on http://www.princeton.edu/ otorres/Panel101.pdf. Accessed 5 July 2007

Submit your manuscript to a SpringerOpen ${ }^{\circ}$ journal and benefit from:

- Convenient online submission

- Rigorous peer review

Open access: articles freely available online

High visibility within the field

- Retaining the copyright to your article

Submit your next manuscript at $\gg$ springeropen.com 